\author{
SERIES "LUNG INFECTIONS AND LUNG IMMUNITY" \\ Edited by M. Spiteri and L.P. Nicod \\ Number 4 in this Series
}

\title{
The immunology of virus infection in asthma
}

\author{
S.D. Message, S.L. Johnston
}

\begin{abstract}
The immunology of virus infection in asthma. S.D. Message, S.L. Johnston. (CERS Journals Ltd 2001.

ABSTRACT: The respiratory tract is commonly infected by a range of viruses with overlapping pathologies. The majority of episodic exacerbations of asthma are associated with viral infection, in particular with rhinovirus infections.

Experimental rhinovirus infection in human volunteers provides a useful model of natural virus-induced asthma. The asthmatic airway is characterized by an infiltrate of eosinophils and T-lymphocytes expressing the type 2 cytokines interleukin (IL)-4, IL-5 and IL-13. An effective antiviral immune response requires early viral clearance and appropriate termination of the immune response to minimize associated immunopathology and tissue damage.

The antiviral immune response is made up of innate (nonspecific) and specific components, and requires the coordinated actions of many different cell types including neutrophils, macrophages, eosinophils, dendritic cells, epithelial cells, mast cells, natural killer cells and B- and T-lymphocytes. Coordination of this response involves numerous cytokines and chemokines. T-lymphocytes expressing type 1 cytokines including interferon- $\gamma$ play a key role.

Pre-existing asthmatic inflammation in the lower airway may modify the immune response to viral infection by altering the balance of $T$-cell cytokine expression from type 1 towards a type 2 in what is always a mixed response. The consequence is delayed viral clearance, persistent virus-induced inflammation and amplification of the allergic inflammation.
\end{abstract}

Eur Respir J 2001; 18: 1013-1025.
National Heart and Lung Institute Dept of Respiratory Medicine, Imperial College School of Medicine at St Mary's, London, UK.

Correspondence: S.D. Message National Heart and Lung Institute Dept of Respiratory Medicine Imperial College School of Medicine at St Mary's

Norfolk Place

London W2 1 PG

UK

Fax: 442072628913

Keywords: Asthma

immune response

respiratory virus infections

Received: March 222001

Accepted after revision May 82001

This work was supported by the Medical Research Council and the British Lung Foundation.
Infection of the respiratory tract by viruses is common and can result in a variety of specific syndromes such as the common cold, pharyngitis, tracheobronchitis, croup, bronchiolitis or pneumonia. Such syndromes may be superimposed on a background of pre-existing chronic respiratory disease. One such chronic respiratory disease is asthma. Numerous virus types can cause respiratory disease. Infection may be localized to the respiratory tract, as in respiratory syncytial virus (RSV) infant bronchiolitis, or part of a generalized systemic illness such as measles or chickenpox. Each viral pathogen can produce more than one clinical syndrome and each syndrome may be caused by a range of different viruses (table 1). The pathology resulting from virus infection is influenced by host factors including age, previous infection or immunization, pre-existing respiratory or systemic disease and immunosuppression/compromise. The nature and severity of disease observed is dependent both on the direct harmful effects of the virus itself and on damage caused to host tissues as a consequence of the host immune response to the virus. Some immunopathology may be unavoidable if the host is to eradicate the virus. An ideal immune response would result in early elimination of the virus with minimum harm to the host.

Asthma is a disease of major importance affecting $20-33 \%$ of children in the UK [1]. The health costs of this condition are enormous in terms of absence from work or school, general practise consultations, hospital admissions and mortality. It is a multifaceted syndrome involving atopy, bronchial hyperreactivity and immunoglobulin (Ig)-E and non-IgE-mediated acute and chronic immune responses. The asthmatic airway is characterized by an infiltrate of eosinophils and of T-lymphocytes expressing the type 2 cytokines, interleukin (IL)-4, IL-5 and IL-13. Trigger factors associated with acute exacerbations of asthma include exposure to environmental allergens, especially animals, moulds, pollens and mites, cold, exercise and drugs. The link between respiratory infection and asthma exacerbation is well established, although

Previous articles in this Series: No. 1: Pilette C, Ouadrhiri Y, Godding V, Vaerman J-P, Sibille Y. Lung mucosal immunity: immunoglobulin-A revisited. Eur Respir J 2001; 18: 571-588. No. 2: Lambrecht BN, Prins JB, Hoogsteden HC. Lung dendritic cells and host immunity to infection. Eur Respir $J$ 2001; 18: 692-704. No. 3: Moore BB, Moore TA, Toews GB. Role of T- and B-lymphocytes in pulmonary host defences. Eur Respir J 2001; 18: 846-856. 
Table 1.-Respiratory viruses and disease syndromes

\begin{tabular}{|c|c|c|c|c|c|c|}
\hline Virus type & Serotypes & Common cold & Asthma exacerbation & Pneumonia & Bronchitis & Bronchiolitis \\
\hline Rhinovirus & $1-100+$ & ++ & +++ & $+/-$ & + & + \\
\hline Coronavirus & 229E OC43 & ++ & ++ & & & \\
\hline Influenza & $\mathrm{A}, \mathrm{B}, \mathrm{C}$ & + & + & ++ & + & \\
\hline Parainfluenza & $1,2,3,4$ & + & + & $+1-$ & ++ & + \\
\hline RSV & $\mathrm{A}, \mathrm{B}$ & + & + & + & + & +++ \\
\hline Adenovirus & $1-43$ & + & + & ++ & + & + \\
\hline
\end{tabular}

RSV: respiratory syncytial virus; +: well-recognized; ++: common; +1+: major cause; +/-: occasional/rare.

incompletely understood. In the $1950 \mathrm{~s}$, this association was attributed to bacterial allergy [2], but it is now clear that the majority of exacerbations are due to viral rather than bacterial infection.

\section{The antiviral immune response}

Current concepts of a typical antiviral immune response, as reviewed in detail elsewhere [3, 4], result from a huge body of research carried out using human volunteers, patients and experimental animals, especially inbred mice. The results of animal studies may not be directly applicable to the outbred human population, but are valuable because ethical considerations often limit direct investigation of the human immune system. A typical response involves a combination of nonspecific (innate) and specific immunity.

Nonspecific elements include: phagocytes (e.g. neutrophils and macrophages) that engulf and destroy viruses; natural killer (NK) cells that recognize and destroy virus-infected cells on the basis of alterations to normal cell surface proteins; cells including NK cells, neutrophils, macrophages, mast cells, basophils and epithelial cells that release cytokines (e.g. the interferons), which have immunoregulatory or antiviral actions; and components of body fluids that are capable of neutralizing viral infections independently, or in combination with antibodies.

Specific immunity involves the production of antibodies by B-lymphocytes and the activities of cytotoxic T-cells following the processing and presentation of viral antigens by additional cells of the immune system, the most important of which are probably the dendritic cells. An important feature of specific immunity is memory, which modifies the overall response to re-infection by a previously encountered respiratory virus and alters the timing and magnitude of contributions due to the different components.

In a primary infection, the virus multiplies in the respiratory tract, reaching peak levels at $\sim 2$ days. Type I interferons (IFNs) are first detected at this time, peaking at day 3 and falling to an undetectable level by day 8 . IFNs activate NK cells, which are first detectable at day 3 and then peak at day 4 . In addition to the destruction of virally-infected cells, NK cells release cytokines, including IFN- $\gamma$ that activate additional inflammatory cells in the airway. Such nonspecific immune mechanisms are essential for early defence against the virus during the first few days after infection. At this early stage of the antiviral immune response, viral antigens are processed locally in regional lymph nodes by dendritic cells and they are then presented to T-cells. CD4+ and CD8+ T-cells are detectable at day 4 and day $6 . \mathrm{CD} 8+$ cytotoxic T-cell responses peak at day 7 , then generally decline, becoming undetectable by day 14 . However, memory CD4+ and CD8+ responses may persist for life. T-cell recruitment is dependent both on the production of chemokines and on alterations in the expression of adhesion molecules on the endothelium of inflamed tissues. Time is also required to generate B-cell responses. Mucosal IgA may be detected at day 3, serum $\operatorname{IgM}$ at day 5-6 and $\operatorname{IgG}$ at day 7-8; they all then increase in amount and avidity for a period of 2-3 weeks. IgA falls to undetectable levels after 3-6 months, whereas serum IgG may remain detectable for life. Specific immune mechanisms such as CD8+ T-cells and Ig are responsible for the eradication of the infectious virus usually within 7 days after infection.

A secondary infection with the same virus results in rapid mobilization of $\mathrm{B}$ - and $\mathrm{T}$-cell-specific immunity, with an earlier T-cell peak coinciding with the NK cell peak at day 3-4. If re-infection is with the same serotype, a rapid increase in levels of pre-existing neutralizing antibodies may limit viral replication to such an extent that infection is clinically silent. As fewer cells are infected, there is relatively less activation of nonspecific immunity and it may be difficult to detect a CD8+ T-cell response.

Is this classical immune response to respiratory virus infection modified in the context of asthma? This question is the subject of the present review.

\section{Epidemiology}

Viral respiratory tract infections are a major cause of wheezing in infants and adult patients with asthma. Their role may have been underestimated in early epidemiological studies because of difficulties with isolation and identification [5]. The introduction of molecular biological techniques (e.g. the polymerase chain reaction (PCR), in situ hybridization, reverse transcriptase (RT)-PCR and in situ PCR) to such studies has implicated viral infection in the majority of asthma exacerbations.

Indirect evidence from population studies has established a significant correlation between the seasonal variation in wheezing episodes in young 
children and peaks of virus identification [6]. Seasonal patterns of identification of respiratory viruses are associated with peaks in hospital admissions for both children and adults with asthma, indicating a role for such infections in severe asthma attacks [7]. Studies that showed an increased rate of virus detection in individuals suffering from asthma attacks have provided direct evidence implicating viral infection in asthma exacerbations. Viruses have been isolated in $10-85 \%$ of asthma exacerbations in children $[6,8-10]$ and in $10-44 \%$ in adults $[11,12]$. The highest rates of identification were found in: 1) studies where subjects were followed prospectively, allowing collection of clinical specimens early during the course of the illness; 2) where PCR-based methods of diagnosis were used in addition to serology and culture; and 3) where the methodology used allowed for detection of rhinoviruses $(\mathrm{RV})$. The rate of detection of viruses between exacerbations, when individuals are asymptomatic, is only $\sim 3-12 \%$. In contrast, a study of transtracheal aspirates in adult asthmatics during exacerbations yielded sparse bacterial cultures, with no correlation to clinical illness and no difference from those of normal subjects [13].

In almost all studies of asthmatics the predominant viruses are RVs, RSVs and parainfluenza viruses. RV alone is detected in $\sim 50 \%$ of virus-induced asthma attacks. Adenoviruses, enteroviruses and coronaviruses are also detected, but less frequently. Influenza is only found during annual epidemics.

Evidence for a role for viruses in exacerbations of other chronic respiratory diseases is more limited. Recent work suggests that virus infection, RV in particular, is important in chronic obstructive pulmonary disease and that viral infections may contribute to the decline in lung function that is observed over time in the patient group studied $[14,15]$.

\section{Experimental virus infection}

Studies of experimental respiratory virus infection in human volunteers are limited by concerns of safety [16]. Many of these studies have, therefore, focused on the experimental innoculation of $\mathrm{RV}$ in allergic rhinitis, mild asthmatics or normal control subjects [17-29]. Such studies provide a useful model of natural virus infection in asthma and offer advantages including: 1) patient selection and monitoring, under controlled conditions, before, during and after infection; and 2) observation of RV-induced effects, including asthma symptomatology, changes in the use of medication, lung function and airway pathology/immunology.

In general, the clinical, physiological and cellular responses to experimental $\mathrm{RV}$ infection in asthma are relatively mild and do not necessarily mimic exactly the events after a natural common cold. It has been suggested that this requires a more complex model including both virus infection and pre-existing increase in allergic airway inflammation. Indeed, recent epidemiological evidence confirms a synergistic interaction between virus infection and allergen exposure in precipitating hospital admissions for asthma. Most studies of experimental virus infection in allergic subjects are performed outside the relevant season for allergen exposure. One recent attempt to provide such a model utilized RV infection in subjects with allergic rhinitis. Individuals received three highdose allergen challenges in the week prior to innoculation to mimic combined allergen exposure and virus infection [30]. Interestingly, prior allergen challenge in this model, somewhat unexpectedly, appeared to protect against a RV cold with delayed nasal leukocytosis, increased generation of the proinflammatory cytokines IL-6 and IL-8 and a delayed, less severe clinical course. There was an inverse correlation between nasal lavage eosinophilia and the severity of cold symptoms. The authors of this study propose that limited high-dose allergen challenge may not reproduce the effects of chronic lowdose allergen exposure and may stimulate the production of anti-inflammatory mediators such as IL-10 or antiviral cytokines such as IFN- $\gamma$ or tumour necrosis factor (TNF)- $\alpha$. Further development of models of combined allergen exposure and virus infection is clearly required.

\section{Rhinovirus infection of the lower airway}

While other respiratory viruses (e.g. influenza, parinfluenza, RSV, adenovirus) are well-recognized causes of lower airway syndromes such as pneumonia and bronchiolitis and are capable of replication in the lower airway, until recently the experimental RV infection model did not provide clear evidence to show that RV infection occurred in the lower airway as well as in the upper respiratory tract. Although the possibility of nasopharyngeal contamination could not be ruled out, RV has been detected in lower airway clinical specimens such as induced sputum [31], tracheal brushings [26] and bronchoalveolar lavage (BAL) [32] both by (RT)-PCR and culture, but for all such specimens, contamination from the nasopharynx could not be excluded. RV has been cultured in cell lines of bronchial epithelial cell origin [33] and replication has been demonstrated in primary cultures of bronchial epithelial cells [34, 35]. The preference of $\mathrm{RV}$ for culture at $33^{\circ} \mathrm{C}$ rather than $37^{\circ} \mathrm{C}$ has been used as an argument against lower airway infection, but now there is evidence that replication does occur at lower airway temperatures [36]. Finally the use of in situ hybridization has demonstrated RV in bronchial biopsies of subjects following experimental infection [34]. These data confirm that RV infection of the lower airway does occur and they directly implicate lower airway infection in the pathogenesis of asthma exacerbations.

\section{Physiological effects of experimental rhinovirus infection}

Subjects with asthma and/or allergic rhinitis exhibit increased pathophysiological effects as a result of RV infection as compared to nonatopic, nonasthmatic controls. With detailed monitoring, it is possible to 
detect reductions both in peak flow [37] and home recordings of forced expiratory volume in one second (FEV1) in atopic asthmatic patients in the acute phase of experimental RV16 infection [24]. There is an enhanced sensitivity to histamine and allergen challenge after RV16 inoculation in nonasthmatic atopic rhinitic subjects [19, 29]. RV16 increases asthma symptoms, coinciding with an increase in the maximal bronchoconstrictive response to methacholine $\leqslant 15$ days after infection [20]. There is a significant increase in sensitivity to histamine in asthmatic subjects after RV16 infection, most pronounced in those with severe cold symptoms [25].

\section{Interactions between virus infection and asthmatic airway inflammation}

The interaction of respiratory virus infection and chronic asthmatic airway inflammation results in respiratory symptoms that are more severe than those suffered by nonasthmatic individuals. The detailed immunological mechanisms underlying this interaction are currently unclear. The disease syndrome following viral infection is a consequence both of the direct harmful effects of the virus and of immunopathology resulting from the host immune response. In an asthmatic individual, exacerbation may occur because of the functional interaction between viral pathology and asthmatic pathology (i.e. through different mechanisms with the same end effect on function or by sharing the same pathogenetic mechanism in an additive or even in a synergistic fashion). Pre-existing asthmatic inflammation might interfere with an effective antiviral response, thus allowing the virus itself to cause increased airway damage. Alternatively, virus infection might increase the sensitivity of the asthmatic airway to trigger factors such as allergen exposure. In fact, it is likely that virus-induced asthma exacerbations occur because of a combination of these four types of interaction. The increased severity of symptoms (including lower respiratory symptoms), seen in nonasthmatic subjects with allergic rhinitis during viral infection suggests that the atopic phenotype itself is important in determining the clinical syndrome following infection by respiratory viruses. However, it is possible that virus infection, in some way, amplifies subclinical allergic lower airway inflammation already present prior to infection.

Table 2 summarizes some of the current hypotheses proposed to explain the mechanisms of exacerbation of asthma following respiratory virus infection. The evidence supporting these hypotheses is reviewed in detail later.

\section{Effects of viruses on airway epithelial cells}

Respiratory viruses enter into and replicate within epithelial cells lining the lower airways. Entry is dependent on interaction with specific receptors, for example intercellular adhesion molecule (ICAM)-1 in the case of the major group RVs and the low density
Table 2.-Current hypotheses for the pathogenesis of virus-induced asthma exacerbations

\begin{tabular}{|c|c|}
\hline Epithelial disruption & $\begin{array}{l}\text { Reduced ciliary clearance } \\
\text { Increased permeability } \\
\text { Loss of protective functions } \\
\text { Kinins }\end{array}$ \\
\hline Mediator production & $\begin{array}{l}\text { Complement } \\
\text { Arachidonic acid metabolites } \\
\text { Nitric oxide } \\
\text { Reactive oxygen products }\end{array}$ \\
\hline $\begin{array}{l}\text { Induction of } \\
\text { inflammation }\end{array}$ & $\begin{array}{l}\text { Cytokines } \\
\text { Chemokines } \\
\text { Immune cell activation } \\
\text { Adhesion molecule induction }\end{array}$ \\
\hline IgE dysregulation & $\begin{array}{l}\text { Increased total IgE } \\
\text { Antiviral IgE production }\end{array}$ \\
\hline Airway remodelling & $\begin{array}{l}\text { Airway smooth muscle } \\
\text { Fibroblasts } \\
\text { Myofibroblasts } \\
\text { Growth factors }\end{array}$ \\
\hline $\begin{array}{l}\text { Alterations of neural } \\
\text { responses }\end{array}$ & $\begin{array}{l}\text { Increased cholinergic sensitivity } \\
\text { Neuropeptide metabolism } \\
\text { modulation } \\
\beta \text {-Adrenergic receptor dysfunction }\end{array}$ \\
\hline
\end{tabular}

IgE: immunoglobulin-E.

lipoprotein receptor in the case of the minor group RVs. Influenza viruses bind sialic acid residues via haemaglutinin.

The upregulation of ICAM-1 in the asthmatic airway is one explanation for the increased severity of RV infection. RV itself has been shown to further upregulate ICAM-1 in bronchial biopsies, following experimental RV infection [38]. In nasal epithelial cells obtained by brushings from atopic subjects, basal levels of ICAM-1 were increased relative to nonatopic subjects and were elevated in the relevant season for peak allergen exposure. Nasal epithelial cells from atopic subjects showed further upregulation after in vitro culture with allergen. The highest basal level of expression of ICAM-1 was found on nasal polyp epithelial cells and this was increased further after infection with RV14. Viral titres recovered after RV14 infection were significantly higher for polyp epithelial cells than for nonatopic and atopic nonpolyp epithelial cells [39].

In vitro $\mathrm{RV}$ increases expression of both ICAM-1 and vascular cell adhesion molecule-1 in cultures of primary bronchial epithelial cells and in the A549 respiratory epithelial cell line, via a mechanism involving the transcription factor nuclear factor $(\mathrm{NF})-\kappa \mathrm{B}[40,41]$. Inhibition of the upregulation of ICAM-1 might be expected to improve the course of RV infection. One effect of corticosteroids is to inhibit NF- $\mathrm{KB}$ [42]. In A549 cells as well as primary bronchial epithelial cells, pretreatment with three different corticosteroids, (i.e. hydrocortisone, dexamethasone and mometasone furoate), inhibits RV16induced increases in ICAM-1 surface expression, messenger ribonucleic acid (mRNA) and promoter activation, without alteration of virus infectivity or replication [43]. Disappointingly, a study of inhaled corticosteroids in asthmatics prior to experimental RV 
infection failed to show a reduction of virus-induced ICAM-1 expression in bronchial biopsies [38]. It is possible, however, that a longer course and/or a higher dose of inhaled steroid, or administration of oral steroids, might have demonstrated a significant effect.

The extent of epithelial cell destruction observed in the airway varies according to virus type. Influenza typically causes extensive necrosis [44], whereas RV causes little or only patchy damage. Destruction of epithelial cells results in an increase in epithelial permeability, increased penetration of irritants and allergens and exposure of the extensive network of afferent nerve fibres. These effects may contribute to increased bronchial hyperresponsiveness.

There is increasing evidence that the epithelium does not simply act as a physical barrier, but has important regulatory roles. Epithelial cells contribute to the immune response following virus infection by producing cytokines and chemokines (fig. 1). They may also act as antigen-presenting cells, particularly during secondary respiratory viral infections. Furthermore, epithelial cells express major histocompatibility complex (MHC) class I and the co-stimulatory molecules B7-1 and B7-2, and this expression is upregulated in vitro by RV16 [45].

Inflammation is a central event both in asthma and viral infection. The processes involved include interacting cascades from the complement, coagulation, fibrinolytic and kinin systems of the plasma as well as cell-derived cytokines, chemokines and arachidonic acid metabolites. The understanding of the interaction of viruses with these cascades in asthma is incomplete, and it is likely that different viruses interact with each system to different extents. However, it is reasonable to believe that in all cases the initial trigger of the inflammatory reactions is an epithelial cell-virus interaction.

A multitude of inflammatory mediators are generated or act on the epithelial surface. Bradykinin, a polypeptide consisting of nine amino acids, is generated from plasma precursors as part of the inflammatory process and has been shown to be present in the nasal secretions of RV-infected individuals [46]. Given intranasally, bradykinin is able to reproduce some of the symptoms of the common cold, such as sore throat and rhinitis [47]. Although the presence of kinins in the lungs of virus-infected individuals has not been reported, they are present both in the upper and lower airways in allergic reactions [48-50].

Some viruses may also cause complement-mediated damage. Complement components (C) bind to epithelial cells both in vitro and in vivo during RSV infections. $\mathrm{C} 3 \mathrm{a}$ and $\mathrm{C} 5 \mathrm{a}$ are increased in human volunteers infected with influenza A virus [51].

Nitric oxide (NO) is produced by diverse sources including epithelial, endothelial and smooth muscle cells. In human airways, NO appears to be important in relaxation of the human airway smooth muscle [52]. In experimental animals, parainfluenza virus-induced hyperreactivity correlates with a deficiency in constitutive NO production [53]. On the other hand, in inflamed tissues, NO reacts with superoxide anion
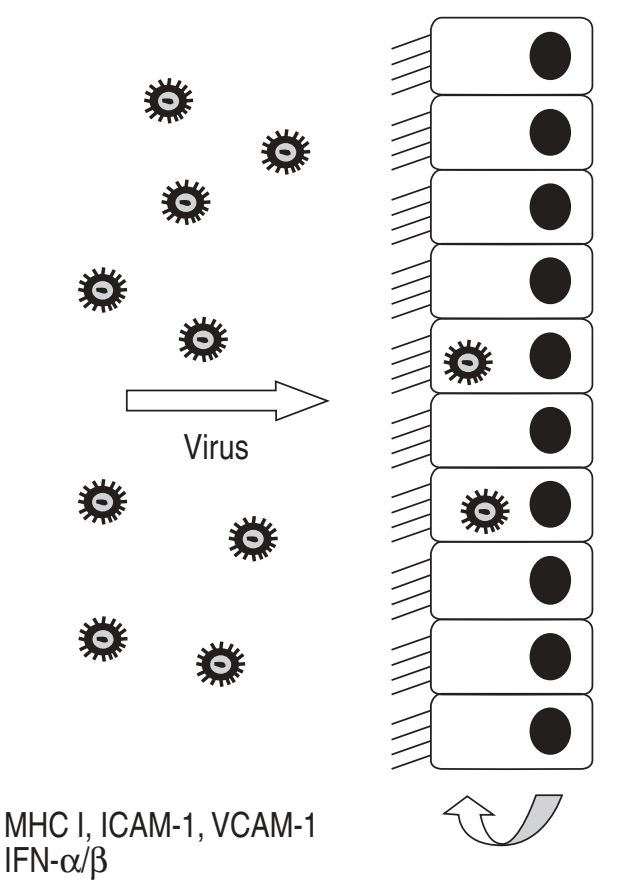
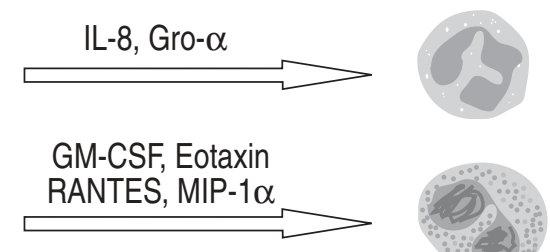

Neutrophils

activation, chemotaxis

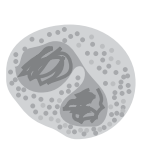

Eosinophils

survival, chemotaxis

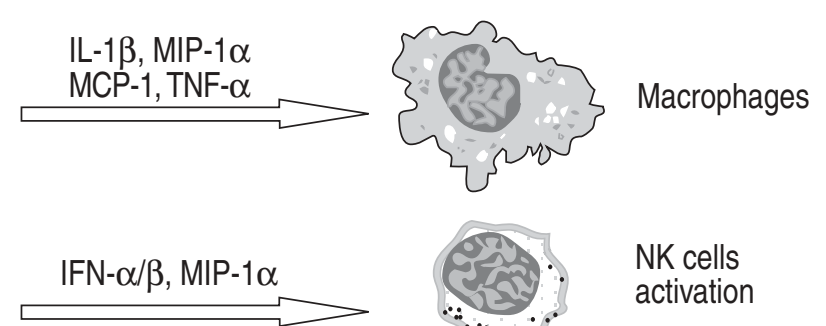

RANTES, IL-6

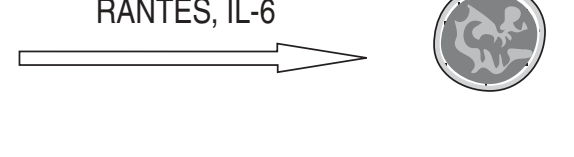

T-lymphocytes

activation, chemotaxis

Fig. 1. - The immunological role of airway epithelial cells in virus-induced asthma exacerbations. Airway epithelial cells participate in the immune response to the respiratory virus, producing a variety of cytokines and chemokines with actions on other cells. In addition, the migration of inflammatory cells is aided by the upregulation of adhesion molecules and interferons help to establish an antiviral state in neighbouring epithelial cells. Upregulation of major histocompatibility complex (MHC) class I may facilitate presentation of viral antigens. IL: interleukin; GM-CSF: granulocyte macrophage colony stimulating factor; RANTES: regulated on activation, normal T-cell expressed and secreted. MIP: macrophage inflammatory protein; MCP: monocyte chemotactic peptide; TNF: tumour necrosis factor; IFN: interferon; ICAM: intercellular adhesion molecule; VCAM: vascular cell adhesion molecule; NK: natural killer. 
generating peroxynitrite, a highly toxic compound, suggesting a dual role for this mediator. Increased levels of exhaled NO are found in nonasthmatic volunteers following natural colds [54] as well as in asthmatic patients after experimental RV infection [55]. In the latter study, an inverse association between NO increase and deterioration of airway hyperresponsiveness was demonstrated, arguing in favour of a protective role for this substance. This is supported further by the observation that NO reduces cytokine production and viral replication in an in vitro model of RV infection [56].

Viral infection of the respiratory tract results in significant changes in the pattern of cytokine expression by a number of cell types. These include cells of the immune system, which may be increased in number and activation status, and other types of cells (e.g. epithelial cells) often considered to be structural, but which in fact contribute significantly to the immune response. Efficient orchestration of the immune response by cytokines is essential for eradication of the virus. Modification of cytokine expression in the airway may contribute to the increased severity of virus infection in asthma.

In vitro studies of bronchial epithelial cell lines have demonstrated the production of a wide range of proinflammatory cytokines (e.g. IL-1, IL-6, IL-11, IFN- $\alpha$, IFN- $\gamma$, TNF- $\alpha$ and granulocyte macrophage colony stimulating factor (GM-CSF)) and the chemokines (e.g. IL-8, regulated on activation, normal T-cell expressed and secreted (RANTES) and macrophage inflammatory protein (MIP)-1 $\alpha$ ) in response to $\mathrm{RV}$ and RSV [33, 57, 58]. In vivo, these cytokines can be found in nasal lavage in association with RV infection [59].

The specific roles of individual cytokines in the human lower airway during viral infection are not well understood, but increasing information is becoming available. IL-1, TNF- $\alpha$ and IL-6 share proinflammatory properties such as the induction of the acute phase response and the activation of both T- and B-lymphocytes. IL-1 enhances the adhesion of inflammatory cells to endothelium, facilitating chemotaxis [60]. TNF- $\alpha$ is a potent antiviral cytokine, but in vitro it increases the susceptibility of cultured epithelial cells to infection by the major group RV, RV14, through upregulation of ICAM-1 [33]. IL-6 has been shown to stimulate $\mathrm{IgA}$-mediated immune responses. IL-11 may also be important in virus-induced asthma [61]. It appears to cause bronchoconstriction by a direct effect on bronchial smooth muscle [58]. Production of this cytokine by human stromal cells in vitro is increased by RV14, RSV and parainfluenza type 3, but not by cytomegalovirus, herpes simplex virus- 2 or adenovirus. In vivo, IL-11 is elevated in nasal aspirates from children with colds; levels correlate with the presence of wheezing. Similarly, the chemokine MIP$1 \alpha$ is increased in nasal secretions during natural viral exacerbations of asthma [62]. Studies in MIP-1 $\alpha$ knockout mice suggest that it mediates pneumonitis as a result of influenza [63].

Viral upregulation of cytokines may be mediated through certain key transcription factors. Increases in IL- 6 and IL- 8 production by cultured epithelial cells due to RV9 are dependent on NF- $\mathrm{BB}[41,64]$ as is the induction of IL-1, IL-6, IL-8, IL-11 and TNF- $\alpha$ by RSV [65, 66].

\section{Effects of viruses on airway smooth muscle cells}

Studies utilizing isolated rabbit tissues and human cultured airway smooth muscle cells suggest that RV16 exposure may have a direct effect on smooth muscle cells, thus resulting in increased contractility to acetylcholine and impaired relaxation to isoprotenol. This effect is dependent on ICAM-1 and appears to involve an autocrine signalling mechanism including upregulation of the production of IL-5 and IL-1 $\beta$ by the airway smooth muscle itself [67]. Whether RV reaches airway smooth muscle cells in sufficient quantity to produce a significant effect by this mechanism in vivo is as yet unknown. The effects of other respiratory viruses on smooth muscle require further investigation.

\section{The cellular immune response to virus infection in the lower airway}

A variety of leukocytes show changes in number, site of accumulation and activation state in response to virus infection. Since these cells are also implicated in asthmatic inflammation of the lower airways, they provide potential sites of interaction between the immunopathologies of virus infection and asthma.

\section{Monocytes and macrophages}

Alveolar macrophages are present in large numbers in the lower airway. They make up $\sim 90 \%$ of the cells seen in BAL from normal volunteers [28]. They are ideally placed for early phagocytosis of virus particles and are likely to play an important role in the immune response through antigen presentation to T-cells and through the production of cytokines and other mediators. RV has been shown to enter human monocytes and macrophages, which express high levels of the major RV receptor ICAM-1. It has not been possible to demonstrate RV replication within alveolar macrophages, although low-grade productive infection has been shown in the human acute monocytic leukaemia cell line, THP-1 [68]. However, entry into monocytes does result in the activation and production of both IL-8 [68] and TNF- $\alpha$ [69]. Similarly, in vitro infection of human monocytes with influenza A causes alterations in structure and activation status as well as in the production of IL-1 $\beta$, IL-6, TNF- $\alpha$, IFN- $\alpha$ and IFN- $\beta$ [70], all of which are effects dramatically potentiated by subsequent exposure to bacterial lipopolysaccharide.

\section{Dendritic cells}

Dendritic cells play a key role in antigen presentation both of allergens and pathogens, which have a 
capacity to induce primary immune responses. They may also play a role in the regulation of the T-cellmediated immune response [71]. There is increasing knowledge of the immunobiology of these cells, but they are not well studied in the context of viral exacerbations of asthma.

\section{Lymphocytes}

Bronchial biopsies demonstrate increases in CD3+, CD4+ and CD8+ within the epithelium and submucosa of both normal and asthmatic subjects, following experimental RV infection [21]. Such increases coincide with peripheral lymphopenia, suggesting increased recruitment of T-cells to the airway; although alternative mechanisms such as reduced apoptosis might also contribute. Since T-cells are believed to be key in the pathogenesis of asthma, the effects of viruses on T-cells are of particular importance.

The normal CD4+ T-cell response to virus infection is thought to be of the T-helper (Th) 1 type. A major Th1 cytokine is IFN- $\gamma$ which, in addition to IFN- $\alpha$ and IFN- $\gamma$ from monocytes and macrophages, plays a role in establishing an "antiviral state" in neighbouring cells. IFN- $\gamma$ has varied effects on the pathogenesis of asthma. It appears to increase basophil and mast cell histamine release [72], but on the other hand inhibits the expression of type 2 cytokines. Production of IFN- $\gamma$ is increased in peripheral blood mononuclear cells (PBMC) [73], and nasal secretions [59] during RV colds and in human and animal models of influenza, parainfluenza and RSV infection $[74,75]$.

There are exceptions where the antiviral response exhibits a Th2 character or a mixture of Th1/Th2. In animal models of RSV, different viral proteins may induce either Th1- or Th2-type responses, and priming with such proteins prior to infection with whole virus can influence the character, effectiveness and associated immunopathology of the immune response [76]. Asthma is believed to be characterized by Th2-type inflammation. Many studies have demonstrated mutual inhibition of Th1 and Th2 cells [77, 78]. Therefore, it is possible that within an airway with a pre-existing Th2-type allergic asthmatic microenvironment there may be inhibition of the normal effective Th1-type antiviral immune responses, or that responses may be skewed towards inappropriate and potentially harmful Th2 types.

In a recent study of experimental RV16 infection in subjects with allergic rhinitis or asthma, the balance of airway Th1 and Th 2 cytokines in sputum induced by viral infection was found to be related to clinical symptoms and viral clearance. Although protein could not be detected in sputum due to the presence of inhibitors of the enzyme-linked immunosorbent assay used, there were increases in mRNA, as determined by semiquantitative RT-PCR both for IL-5 and IFN- $\gamma$. An inverse correlation was demonstrated between the ratio of IFN- $\gamma$ mRNA to IL-5 mRNA and peak cold symptoms. In addition, subjects with RV16 still detectable 14 days after innoculation had lower
IFN- $\gamma /$ IL- 5 ratios during the acute phase of the cold than those subjects who had cleared the virus [79].

CD8+ T-cells are important effector cells in specific cell-mediated antiviral immunity. These cells also demonstrate polarization of cytokine production (the major cytokine produced by cytotoxic T-cell (Tc)1 cells being IFN- $\gamma$ and they are also believed to play a role in the regulation of CD4 Th1/Th2 balance [80]. In a murine model of asthma, the induction of bystander CD4+ Th type 2 immune responses to ovalbumin resulted in a switch from virus-peptide specific CD8+ $\mathrm{T}$-cells in the lung to the production of Tc2 cytokines, including IL-5 with (after challenge with virus peptide) the induction of airway eosinophilia [81]. If such a mechanism occurs in humans, it would suggest a means by which CD8 antiviral function could be inhibited at the same time as CD8 amplification of allergic inflammation through IL-5 induction of airway eosinophilia.

\section{Mast cells and basophils}

Mast cells and basophils are important sources of inflammatory mediators, characteristic of allergic inflammation in asthma. Mast cell basal and stimulated histamine release increases after viral infection [75]. Airway mast cell numbers are upregulated in a rat model of parainfluenza infection. Several viruses can enhance basophil IgE-mediated histamine release, but the role of this cell in human asthma is controversial.

Mast cells are also important sources of inflammatory mediators. Their function and localization suggest an early interaction with viruses. Leukotriene (LT) $\mathrm{C}_{4}$ is one of the major mediators responsible for the late phase of bronchospasm in asthma. During RSV infection increased levels of $\mathrm{LTC}_{4}$ were found in the nasopharyngeal secretions of infants [82]. Levels correlated well with the symptoms of the disease and concentrations in infants presenting with bronchiolitis were five-fold higher than in those with only upper respiratory tract symptomatology. Cultured alveolar macrophages can be infected with parainfluenza virus and respond with an increase in arachidonic acid metabolism. Several of the products of this pathway are known inducers of airway constriction, including $\mathrm{LTC}_{4}, \mathrm{LTD}_{4}$, prostaglandin $(\mathrm{PG}) \mathrm{F}_{2 \alpha}$, and thromboxanes and/or stimulants of mucous secretion such as $\mathrm{PGF}_{2 \alpha}, \mathrm{LTB}_{2}$ and 5-hydroxyeicosatetraenoic acid [83].

\section{Eosinophils}

Eosinophils are increased in bronchial epithelium in biopsies taken from both normal and asthmatic human volunteers following experimental RV infection; in a small study, eosinophilic inflammation persisted for up to 6 weeks in asthmatic subjects [21]. In allergic rhinitic subjects, experimental RV infection increased BAL eosinophils following segmental allergen challenge, an effect similarly persisting for 6 weeks [28]. In addition, increased levels of 
eosinophil cationic protein were found in the sputum of RV-infected subjects [23].

Eosinophils accumulate in the airway and are under the influence of IL-5, GM-CSF, IL-8, RANTES and eotaxin [84]. Expression of the potent eosinophil chemoattractant RANTES is increased in nasal secretions of children with natural virus-induced asthma exacerbations [62]. RANTES is upregulated in primary nasal epithelial cell cultures by RSV [85] and RV [35]. GM-CSF is believed to be important in eosinophil production in the bone marrow and in prolonging eosinophil survival [84]. However, levels do not appear to be increased during viral infections of the upper respiratory tract $[62,86]$.

This data suggest a pathogenic role for eosinophils in virus-induced asthma, however, a protective role is also possible. When allergic rhinitic subjects were infected with RV after high-dose allergen challenge, the severity and duration of cold symptoms were inversely correlated to the nasal lavage eosinophil count prior to infection [30]. Eosinophils may contribute to antigen presentation during virus infection. Eosinophils purified from PBMC and pretreated with GM-CSF bind RV16 via ICAM-1 and present viral antigen to RV16-specific T-cells, thus inducing proliferation and secretion of IFN- $\gamma$. Eosinophils are known to have antiviral actions in parainfluenzainfected guinea pigs [87]. Also, eosinophil-derived neurotoxin and cationic protein exhibit ribonuclease activity and reduce RSV infectivity [88]. As a result, the role of the eosinophil in the antiviral immune response requires further evaluation.

\section{Neutrophils}

Neutrophils are recruited early in viral infection in response to the production of the chemokine IL- 8 by epithelial cells and activated neutrophils, and they are a prominent feature of severe asthma. Induced sputum studies in asthmatic and nonasthmatic volunteers demonstrate a significant increase in sputum neutrophils at day 4 of a natural cold, correlating with sputum IL-8 [89]. Similar results were obtained in induced sputum taken 2 and 9 days after experimental RV16 infection in asthmatic subjects. Intracellular staining demonstrated that the increase in cells positive for IL-8 at day 2 could be attributed to the increase in IL-8 positive neutrophils [23]. The chemokine IL-8 is a potent chemoattractant for neutrophils, but it also acts on lymphocytes, basophils and primed eosinophils. An increase in IL-8 has been found in nasal lavage from children with natural colds [59]. Experimental infection of atopic asthmatics with RV16 resulted in elevated IL-8 in nasal lavage, and this correlated with cold and asthma symptom scores as well as a fall in the histamine provocative concentration causing a $20 \%$ fall in FEV1 [25]. Sputum from asthmatics with asthma exacerbations has elevated both IL-8 and neutrophilia [90]. A study of experimental virus-induced asthma in children also demonstrated elevated IL-8 and neutrophilia in nasal aspirates during the acute phase of infection, and levels of neutrophil myeloperoxidase correlated with symptom severity [91]. Such studies suggest a prominent role for the neutrophil in tissues damage during virus-induced asthma.

\section{Natural killer cells}

NK cells are an important part of the innate immune response, their function being the elimination of a variety of target cells including virus-infected cells and the modulation of adaptive immunity towards viruses [92]. Cell killing by NK cells may occur through natural killing, antibody-dependent cellular cytotoxicity or apoptotic killing of Fas-positive target cells via membrane-bound FasL. The ability to directly kill virus-infected cells is regulated by a balance between inhibitory and activating receptors [93]. Killer inhibitory receptors, Ig-like receptors that recognize human leukocyte antigen (HLA)-A, -B or $-\mathrm{C}$ molecules, and the lectin-like CD94/NKG2A receptor that interacts with HLA-E allow NK cells to recognize cells expressing normal self MHC class I [94]. Loss of inhibition occurs if potential target cells have lost class I expression following virus infection, or if they display abnormal class I/peptide complexes.

NK cells are rapid and efficient producers of cytokines such as IFN- $\gamma$, important both in early viral infection in the antigen-independent activation of antigen-presenting cells such as macrophages, dendritic cells and epithelial cells, and for biasing the development of CD4+ Th1 and CD8+ Tc1 cells. The cytokines and chemokines shown to enhance the activities of $\mathrm{NK}$ cells in vitro and in vivo include IFN- $\alpha / \beta$, IFN- $\gamma$, TNF- $\alpha$, IL-2, IL-12, IL-15, IL-18, MIP-1 $\alpha$, MIP-1 $\beta$, monocyte chemotactic peptide-1, -2 , and -3 and RANTES. Transforming growth factor (TGF)- $\beta$ and IL-10 inhibit NK cell activity [95]. Type 2 cytokines may also modulate NK function, increasing NK type 2 activities and decreasing NK type 1 activities. Human NK cells, cultured in a medium supplemented with IL-4, differentiated into NK type 2 cells that secreted IL-5 and IL-13. When cultured in the presence of IL-12, these NK cells differentiated into NK type 1 cells secreting IL-10 and IFN- $\gamma$. IL-4 and IL-13 have also been shown to suppress IL-2induced cytolytic and proliferative activities as well as IFN- $\gamma$ production of human NK cells [96]. NK cell production of IL-5 is enhanced by IL-4 and reduced by IL-10 and IL-12 [97]. In a mouse model of asthma, intracellular staining of NK cells has demonstrated IL-5 production, and depletion of NK cells has resulted in reduced airway eosinophilia [98].

The function of NK cells in the asthmatic airway is as yet unexplored. It may be that, in an airway environment rich in type 2 cytokines, NK type 1 function and effective antiviral activity are inhibited. If this is the case, then a key component of the early immune response would be deficient and viral clearance would be impaired. In addition, if NK type 2 function is favoured by the asthmatic microenvironment, production of type 2 cytokines by NK cells in response to virus infection might be one mechanism for amplification of allergic inflammation. 
These hypotheses are as yet untested in human studies of experimental virus infection.

\section{B-lymphocytes and interaction of viruses with immunoglobulin-E-dependent mechanisms}

An elevated serum total and allergen-specific IgE are features of "extrinsic" or atopic asthma. IgEmediated mechanisms are certainly important in the pathophysiology of extrinsic asthma. Recent studies suggest a similar airway pathology both in extrinsic and "intrinsic" nonatopic asthma [99], where there is an absence of specific serum $\operatorname{IgE}$ and negative skinprick tests to aeroallergens. It has been suggested that there may be the production of local IgE to, as yet, unknown environmental allergens in intrinsic asthma. Upregulation of total IgE or virus/allergen-specific $\mathrm{IgE}$, locally or systemically during respiratory virus infection, would be expected to contribute both to the duration and severity of symptoms of an asthma exacerbation.

Intranasal challenge with RV39 results in an increase in total serum IgE in allergic rhinitic subjects, but no increase in pre-existing allergen-specific $\mathrm{IgE}$ [100]. Influenza A infection did not change the total $\mathrm{IgE}$ of asthmatic children. However, increases were observed in specific serum IgE to house dust mite as well as in ex vivo proliferative and IL-2 responses of lymphocytes challenged with house dust mite allergen [101]. In a study of RSV infection in infants, the development of serum RSV-specific IgE occurred more frequently in atopics and correlated with clinical wheezing, histamine levels in nasal secretions, and hypoxia [102]. There is no information, as yet, on the presence of local virus-specific $\operatorname{IgE}$ in the airway during asthma exacerbations.

\section{The effects of pre-existing immunity on virus-induced exacerbations of asthma}

The effect of pre-existing immunity on virusinduced exacerbation of asthma is an area that requires further investigation.

The presence of pre-existing serum-neutralizing antibodies to RV39 and to RV-Hanks modify the clinical course of experimental infection in human subjects [103, 104]. Local IgA and IgG, passing from the vasculature into the pulmonary interstitium, contribute to viral clearance. There are, however, $>100$ recognized serotypes of $\mathrm{RV}$, thus making repeated infection with the rhinoviruses to which an individual lacks appropriate antibodies a common experience.

T-cell responses to RV demonstrate MHC class I restricted cross-reactivity between serotypes due to specificity for conserved epitopes within the viral capsid proteins 1-3 [105]. RV16- and RV49-specific T-cell clones from human peripheral blood demonstrate recognition of both serotype-specific and shared-viral epitopes [106]. Vigorous proliferation of, and IFN- $\gamma$ production by, PBMC in response to RV16 in seronegative subjects is associated with reduced viral shedding after innoculation [107]. As a consequence of serotype cross-reactivity, recurrent infection with RV of different serotypes would be expected to modify $\mathrm{T}$-cell responses to subsequent infection, either enhancing the antiviral response or, in the case of asthmatic subjects, further amplifying allergic inflammation.

Immunization against $\mathrm{RV}$ is not currently practical because of the large number of serotypes, and in the case of other respiratory viruses, immunization can have unexpected consequences. Vaccination of susceptible individuals against prevalent strains of influenza provides protection against disease. Unfortunately, infant trials of a formalin-inactivated, alum-adjuvanted vaccine for RSV were less successful, resulting in a high proportion of vaccinated infants developing lower respiratory tract disease (similar to severe bronchiolitis of infancy) when infected with RSV later in childhood. The vaccine induced complement-fixing and neutralizing RSV antibodies, but appeared to sensitize the vaccinees to develop significant immunopathology upon natural infection with the virus.

\section{Future directions}

Respiratory viruses are important triggers of wheezing illness or asthma. $\mathrm{RV}$ is common in all age groups, and RSV is most important in infants and young children. The mechanisms involved in virusinduced asthma exacerbations are complex and incompletely understood. The pathology observed in the airway is dependent on virus type. RSV and influenza are capable of causing extensive epithelial necrosis, whilst RV generally produces less destruction. Overall, the disease syndrome suffered by the host results from a combination of direct viral effects on lung tissues and of immunopathology associated with the immune response to the virus, some of which may be unavoidable if the virus is to be eliminated. The virally-infected epithelial cell is an important component of the antiviral immune response, producing cytokines and chemokines capable of activating and recruiting a variety of other cells including lymphocytes, eosinophils and neutrophils. Efficient clearance of a virus is orchestrated by antibodies and by T-cells producing type 1 cytokines. The asthmatic airway is rich in type 2 cytokines and this may result in virus-specific T-cells with type 2 or mixed type $1 /$ type 2 character. If this is the case, then virus infection could be followed both by an inefficient antiviral immune response, with delayed viral clearance, and by amplification of ongoing asthmatic inflammation; the consequence of this interaction is severe, often causing prolonged viral illness and exacerbation of asthma (fig. 2).

Current treatment for virus-induced asthma exacerbations is limited to high-dose inhaled and/or oral corticosteroids, which are only partially effective and invariably associated with side effects, and to purely symptomatic treatment with bronchodilators. Antiviral therapy exists for influenza; however, it is not available for the most common respiratory viruses, $\mathrm{RV}$ and RSV. Vaccination is difficult for RV because 


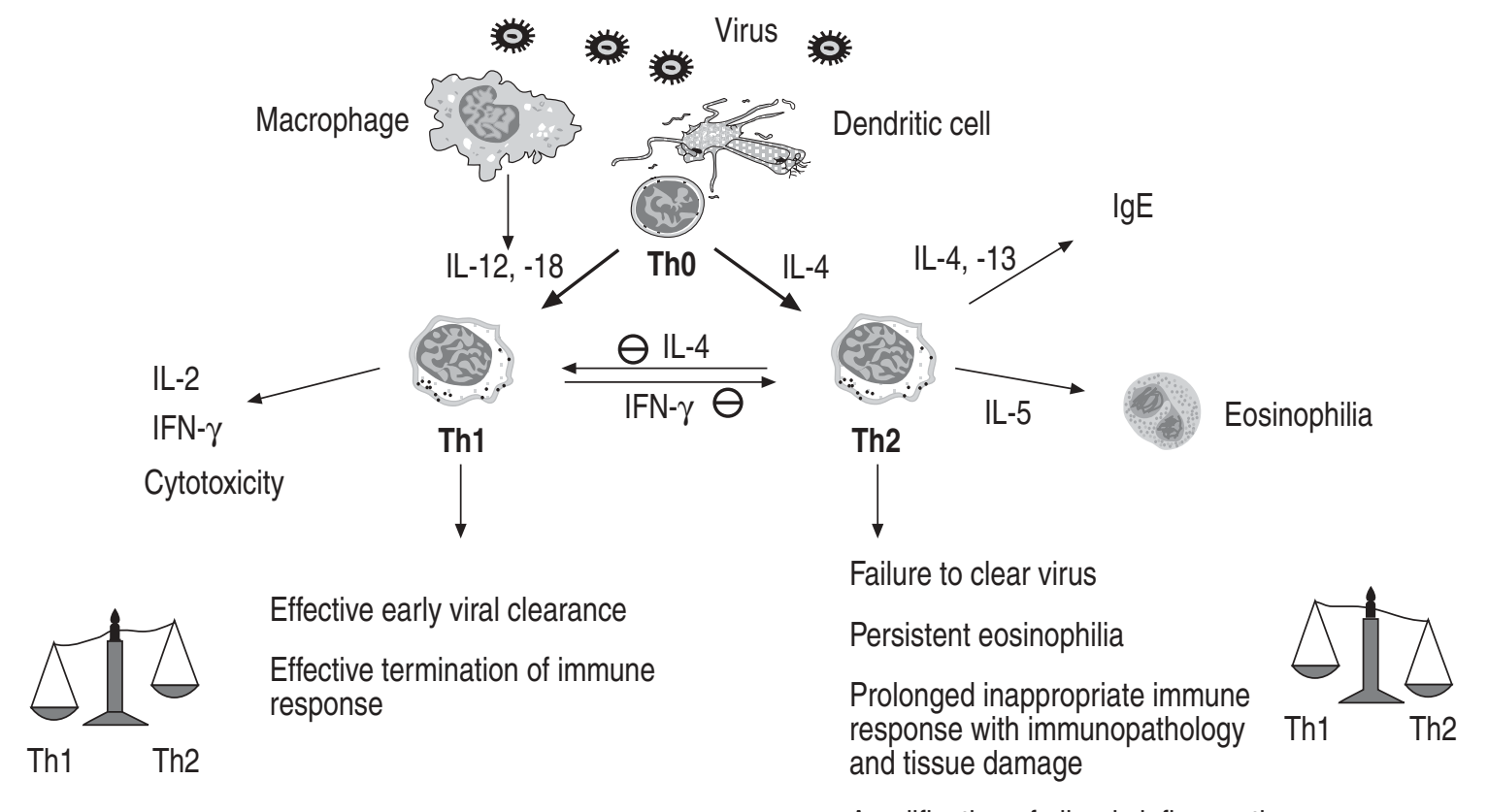

Amplification of allergic inflammation

Fig. 2.-T-helper (Th)1/Th2 balance and the antiviral immune response. Pre-existing asthmatic airway inflammation may modify a predominantly Th1 antiviral immune response, favouring a Th2, or mixed response, which may provide less efficient viral clearance and result in prolonged virus-induced inflammation, increased associated immunopathology and increased tissue damage. IL: interleukin; IgE: immunoglobulin-E; IFN: interferon.

of the many serotypes, and caution surrounds the development of vaccines for RSV, which must be designed to avoid subsequent enhanced immunopathology.

As an alternative approach, virus-induced inflammation could be treated by strategies that promote type 1 responses in individuals with excessive type 2 responses. Further work is needed to elucidate the important sites of interaction between the immunological networks of asthma and of virus infection. Greater knowledge is required if the key targets for therapeutic intervention are to be identified, the aim of which will be to minimize immunopathology, whilst maintaining or enhancing the host antiviral immune response.

\section{References}

1. Kaur B, Anderson HR, Austin J, et al. Prevalence of asthma symptoms, diagnosis, and treatment in 12-14 year old children across Great Britain (International Study of Asthma and Allergies in Childhood, ISAAC UK). BMJ 1998; 316: 118-124.

2. Stevens FA. Acute asthmatic episodes in children caused by upper respiratory bacteria during colds, with and without bacterial sensitization. $J$ Allergy 1953; 24: 221-226.

3. Whitton JL, Oldstone MBA. Immune responses to viruses. In: Fields BN, Knipe DN, Howley PM, ed. Field's Virology. 3rd Edn. Philadelphia, LippincottRaven, 1996; pp. 345-374.

4. Yewdell JW, Bennink JR. Immune responses to viruses. In: Richman DR, Whiteley RJ, Hayden FG, eds. Clinical Virology. New York, Churchill Livingstone, 1997; pp. 271-306.

5. Pattemore PK, Johnston SL, Bardin PG. Viruses as precipitants of asthma symptoms. I. Epidemiology. Clin Exp Allergy 1992; 22: 325-336.

6. McIntosh K, Ellis EF, Hoffman LS, Lybass TG, Eller JJ, Fulginiti VA. The association of viral and bacterial respiratory infections with exacerbations of wheezing in young asthmatic children. J Pediatr 1973; 82: 578-590.

7. Johnston SL, Pattemore PK, Sanderson G, et al. The relationship between upper respiratory infections and hospital admissions for asthma: a time-trend analysis. Am J Respir Crit Care Med 1996; 154: 654-660.

8. Johnston SL, Pattemore PK, Sanderson G, et al. Community study of role of viral infections in exacerbations of asthma in 9-11 year old children. BMJ 1995; 310: 1225-1229.

9. Minor TE, Dick EC, DeMeo AN, Ouellette JJ, Cohen M, Reed CE. Viruses as precipitants of asthmatic attacks in children. JAMA 1974; 227: 292-298.

10. Horn ME, Brain EA, Gregg I, Inglis JM, Yealland SJ, Taylor P. Respiratory viral infection and wheezy bronchitis in childhood. Thorax 1979; 34: 23-28.

11. Nicholson KG, Kent J, Ireland DC. Respiratory viruses and exacerbations of asthma in adults. BMJ 1993; 307: 982-986.

12. Beasley R, Coleman ED, Hermon Y, Holst PE, $\mathrm{O}^{\prime}$ Donnell TV, Tobias M. Viral respiratory tract infection and exacerbations of asthma in adult patients. Thorax 1988; 43: 679-683.

13. Berman SZ, Mathison DA, Stevenson DD, Tan EM, Vaughan JH. Transtracheal aspiration studies in asthmatic patients in relapse with "infective" asthma and in subjects without respiratory disease. $J$ Allergy Clin Immunol 1975; 56: 206-214. 
14. Seemungal TAR, Donaldson GC, Breuer J, Johnston SL, Jeffries DJ, Wedzicha JA. Rhinoviruses are associated with exacerbations of COPD. Am J Respir Crit Care Med 1998; 157: A58.

15. Bhowmik A, Seemungal TA, Sapsford RJ, Wedzicha JA. Relation of sputum inflammatory markers to symptoms and lung function changes in COPD exacerbations. Thorax 2000; 55: 114-120.

16. Gwaltney JMJ, Hendley O, Hayden FG, et al. Updated recommendations for safety-testing of viral inocula used in volunteer experiments on rhinovirus colds. Prog Med Virol 1992; 39: 256-263.

17. Halperin SA, Eggleston PA, Beasley P, et al. Exacerbations of asthma in adults during experimental rhinovirus infection. Am Rev Respir Dis 1985; 132: 976-980.

18. Bardin PG, Fraenkel DJ, Sanderson G, et al. Amplified rhinovirus colds in atopic subjects. Clin Exp Allergy 1994; 24: 457-464.

19. Lemanske RFJ, Dick EC, Swenson CA, Vrtis RF, Busse WW. Rhinovirus upper respiratory infection increases airway hyperreactivity and late asthmatic reactions. J Clin Invest 1989; 83: 1-10.

20. Cheung D, Dick EC, Timmers MC, de Klerk EP, Spaan WJ, Sterk PJ. Rhinovirus inhalation causes long-lasting excessive airway narrowing in response to methacholine in asthmatic subjects in vivo. Am J Respir Crit Care Med 1995; 152: 1490-1496.

21. Fraenkel DJ, Bardin PG, Sanderson G, Lampe F, Johnston SL, Holgate ST. Lower airways inflammation during rhinovirus colds in normal and in asthmatic subjects. Am J Respir Crit Care Med 1995; 151: 879-886.

22. Grunberg K, Kuijpers EA, de Klerk EP, et al. Effects of experimental rhinovirus 16 infection on airway hyperresponsiveness to bradykinin in asthmatic subjects in vivo. Am J Respir Crit Care Med 1997; 155: 833-838.

23. Grunberg K, Smits HH, Timmers MC, et al. Experimental rhinovirus 16 infection. Effects on cell differentials and soluble markers in sputum in asthmatic subjects. Am J Respir Crit Care Med 1997; 156: 609616.

24. Grunberg K, Timmers MC, de Klerk EP, Dick EC, Sterk PJ. Experimental rhinovirus 16 infection causes variable airway obstruction in subjects with atopic asthma. Am J Respir Crit Care Med 1999; 160: 13751380.

25. Grunberg K, Timmers MC, Smits HH, et al. Effect of experimental rhinovirus 16 colds on airway hyperresponsiveness to histamine and interleukin-8 in nasal lavage in asthmatic subjects in vivo. Clin Exp Allergy 1997; 27: 36-45.

26. Halperin SA, Eggleston PA, Hendley JO, Suratt PM, Groschel DH, Gwaltney JM Jr. Pathogenesis of lower respiratory tract symptoms in experimental rhinovirus infection. Am Rev Respir Dis 1983; 128: 806-810.

27. Calhoun WJ, Swenson CA, Dick EC, Schwartz LB, Lemanske RFJ, Busse WW. Experimental rhinovirus 16 infection potentiates histamine release after antigen bronchoprovocation in allergic subjects. Am Rev Respir Dis 1991; 144: 1267-1273.

28. Calhoun WJ, Dick EC, Schwartz LB, Busse WW. A common cold virus, rhinovirus 16, potentiates airway inflammation after segmental antigen bronchoprovocation in allergic subjects. J Clin Invest 1994; 94 : 2200-2208.
29. Gern JE, Calhoun W, Swenson C, Shen G, Busse WW. Rhinovirus infection preferentially increases lower airway responsiveness in allergic subjects. $\mathrm{Am}$ J Respir Crit Care Med 1997; 155: 1872-1876.

30. Avila PC, Abisheganaden JA, Wong H, et al. Effects of allergic inflammation of the nasal mucosa on the severity of rhinovirus 16 cold. J Allergy Clin Immunol 2000; 105: 923-932.

31. Horn ME, Reed SE, Taylor P. Role of viruses and bacteria in acute wheezy bronchitis in childhood: a study of sputum. Arch Dis Child 1979; 54: 587-592.

32. Gern JE, Galagan DM, Jarjour NN, Dick EC, Busse WW. Detection of rhinovirus RNA in lower airway cells during experimentally induced infection. $\mathrm{Am}$ J Respir Crit Care Med 1997; 155: 1159-1161.

33. Subauste MC, Jacoby DB, Richards SM, Proud D. Infection of a human respiratory epithelial cell line with rhinovirus. Induction of cytokine release and modulation of susceptibility to infection by cytokine exposure. J Clin Invest 1995; 96: 549-557.

34. Papadopoulos NG, Bates PJ, Bardin PG, et al. Rhinoviruses infect the lower airways. J Infect Dis 2000; 181: 1875-1884.

35. Schroth MK, Grimm E, Frindt $\mathrm{P}$, et al. Rhinovirus replication causes RANTES production in primary bronchial epithelial cells. Am J Respir Cell Mol Biol 1999; 20: 1220-1228.

36. Papadopoulos NG, Sanderson G, Hunter J, Johnston SL. Rhinoviruses replicate effectively at lower airway temperatures. J Med Virol 1999; 58: 100-104.

37. Bardin PG, Fraenkel D, Sanderson G, van Schalkwyk EM, Holgate ST, Johnston SL. Peak expiratory flow changes during experimental rhinovirus infection. Eur Respir J 2000; 16: 980-985.

38. Grunberg K, Sharon RF, Hiltermann TJ, et al. Experimental rhinovirus 16 infection increases intercellular adhesion molecule-1 expression in bronchial epithelium of asthmatics regardless of inhaled steroid treatment. Clin Exp Allergy 2000; 30: 1015-1023.

39. Bianco A, Whiteman SC, Sethi SK, Allen JT, Knight RA, Spiteri MA. Expression of intercellular adhesion molecule-1 (ICAM-1) in nasal epithelial cells of atopic subjects: a mechanism for increased rhinovirus infection? Clin Exp Immunol 2000; 121: 339-345.

40. Papi A, Johnston SL. Respiratory epithelial cell expression of vascular cell adhesion molecule-1 and its up-regulation by rhinovirus infection via NFkappaB and GATA transcription factors. $J$ Biol Chem 1999; 274: 30041-30051.

41. Papi A, Johnston SL. Rhinovirus infection induces expression of its own receptor intercellular adhesion molecule 1 (ICAM-1) via increased NF-kappaBmediated transcription. J Biol Chem 1999; 274: 9707-9720.

42. Barnes PJ, Adcock IM. Transcription factors and asthma. Eur Respir J 1998; 12: 221-234.

43. Papi A, Papadopoulos NG, Degitz K, Holgate ST, Johnston SL. Corticosteroids inhibit rhinovirus-induced intercellular adhesion molecule-1 up-regulation and promoter activation on respiratory epithelial cells. J Allergy Clin Immunol 2000; 105: 318-326.

44. Hers JF. Disturbances of the ciliated epithelium due to influenza virus. Am Rev Respir Dis 1966; 93: Suppl., 162-177.

45. Papi A, Stanciu LA, Papadopoulos NG, Teran LM, Holgate ST, Johnston SL. Rhinovirus infection induces major histocompatibility complex class I and 
costimulatory molecule upregulation on respiratory epithelial cells. J Infect Dis 2000; 181: 1780-1784.

46. Proud D, Naclerio RM, Gwaltney JM, Hendley JO. Kinins are generated in nasal secretions during natural rhinovirus colds. J Infect Dis 1990; 161: 120-123.

47. Proud D, Reynolds CJ, Lacapra S, Kagey-Sobotka A, Lichtenstein LM, Naclerio RM. Nasal provocation with bradykinin induces symptoms of rhinitis and a sore throat. Am Rev Respir Dis 1988; 137: 613-616.

48. Christiansen SC, Proud D, Cochrane CG. Detection of tissue kallikrein in the bronchoalveolar lavage fluid of asthmatic subjects. J Clin Invest 1987; 79: 188-197.

49. Christiansen SC, Proud D, Sarnoff RB, Juergens U, Cochrane CG, Zuraw BL. Elevation of tissue kallikrein and kinin in the airways of asthmatic subjects after endobronchial allergen challenge. Am Rev Respir Dis 1992; 145: 900-905.

50. Christiansen SC, Zuraw BL, Proud D, Cochrane CG. Inhibition of human bronchial kallikrein in asthma. Am Rev Respir Dis 1989; 139: 1125-1131.

51. Bjornson AB, Mellencamp MA, Schiff GM. Complement is activated in the upper respiratory tract during influenza virus infection. Am Rev Respir Dis 1991; 143: 1062-1066.

52. Nijkamp FP, Folkerts G. Nitric oxide and bronchial reactivity. Clin Exp Allergy 1994; 24: 905-914.

53. Folkerts G, van der Linde HJ, Nijkamp FP. Virusinduced airway hyperresponsiveness in guinea pigs is related to a deficiency in nitric oxide. $J$ Clin Invest 1995; 95: 26-30.

54. Kharitonov SA, Yates D, Barnes PJ. Increased nitric oxide in exhaled air of normal human subjects with upper respiratory tract infections. Eur Respir J 1995; 8: 295-297.

55. de Gouw HW, Grunberg K, Schot R, Kroes AC, Dick EC, Sterk PJ. Relationship between exhaled nitric oxide and airway hyperresponsiveness following experimental rhinovirus infection in asthmatic subjects. Eur Respir J 1998; 11: 126-132.

56. Sanders SP, Siekierski ES, Porter JD, Richards SM, Proud D. Nitric oxide inhibits rhinovirus-induced cytokine production and viral replication in a human respiratory epithelial cell line. J Virol 1998; 72: 934 942.

57. Becker S, Quay J, Soukup J. Cytokine (tumor necrosis factor, IL-6, and IL-8) production by respiratory syncytial virus-infected human alveolar macrophages. J Immunol 1991; 147: 4307-4312.

58. Einarsson O, Geba GP, Zhu Z, Landry M, Elias JA. Interleukin-11: stimulation in vivo and in vitro by respiratory viruses and induction of airways hyperresponsiveness. J Clin Invest 1996; 97: 915-924.

59. Lau L, Corne J, Scott S. Nasal cytokines in the common cold. Am J Respir Crit Care Med 1996; 153 : A866.

60. Proud D, Gwaltney JMJ, Hendley JO, Dinarello CA, Gillis S, Schleimer RP. Increased levels of interleukin1 are detected in nasal secretions of volunteers during experimental rhinovirus colds. J Infect Dis 1994; 169: 1007-1013.

61. Einarsson O, Geba GP, Zhou Z, et al. Interleukin-11 in respiratory inflammation. Ann NY Acad Sci 1995; 762: 89-100.

62. Teran LM, Seminario MC, Shute JK, et al. RANTES, macrophage-inhibitory protein 1alpha, and the eosinophil product major basic protein are released into upper respiratory secretions during virus-induced asthma exacerbations in children. $J$ Infect Dis 1999; 179: 677-681.

63. Cook DN, Beck MA, Coffman TM, et al. Requirement of MIP-1 alpha for an inflammatory response to viral infection. Science 1995; 269: 1583-1585.

64. Johnston SL, Papi A, Bates PJ, Mastronarde JG, Monick MM, Hunninghake GW. Low grade rhinovirus infection induces a prolonged release of IL-8 in pulmonary epithelium. J Immunol 1998; 160: 61726181.

65. Mastronarde JG, He B, Monick MM, Mukaida N, Matsushima K, Hunninghake GW. Induction of interleukin (IL)-8 gene expression by respiratory syncytial virus involves activation of nuclear factor (NF)-kappa B and NF-IL-6. J Infect Dis 1996; 174: 262-267.

66. Bitko V, Velazquez A, Yang L, Yang YC, Barik S. Transcriptional induction of multiple cytokines by human respiratory syncytial virus requires activation of NF-kappa B and is inhibited by sodium salicylate and aspirin. Virology 1997; 232: 369-378.

67. Grunstein MM, Hakonarson H, Maskeri N, Chuang $\mathrm{S}$. Autocrine cytokine signaling mediates effects of rhinovirus on airway responsiveness. Am J Physiol 2000; 278: L1146-L1153.

68. Johnston SL, Papi A, Monick MM, Hunninghake GW. Rhinoviruses induce interleukin- $8 \mathrm{mRNA}$ and protein production in human monocytes. $J$ Infect Dis 1997; 175: 323-329.

69. Gern JE, Dick EC, Lee WM, et al. Rhinovirus enters but does not replicate inside monocytes and airway macrophages. J Immunol 1996; 156: 621-627.

70. Peschke T, Bender A, Nain M, Gemsa D. Role of macrophage cytokines in influenza A virus infections. Immunobiology 1993; 189: 340-355.

71. Banchereau J, Briere F, Caux C, et al. Immunobiology of dendritic cells. Ann Rev Immunol 2000; 18: 767-811.

72. Huftel MA, Swensen CA, Borcherding WR, et al. The effect of T-cell depletion on enhanced basophil histamine release after in vitro incubation with live influenza A virus. Am J Respir Cell Mol Biol 1992; 7: $434-440$.

73. Hsia J, Goldstein AL, Simon GL, Sztein M, Hayden FG. Peripheral blood mononuclear cell interleukin-2 and interferon-gamma production, cytotoxicity, and antigen-stimulated blastogenesis during experimental rhinovirus infection. J Infect Dis 1990; 162: 591-597.

74. Corne JM, Holgate ST. Mechanisms of virus induced exacerbations of asthma. Thorax 1997; 52: 380-389.

75. Folkerts G, Nijkamp FP. Virus-induced airway hyperresponsiveness. Role of inflammatory cells and mediators. Am J Respir Crit Care Med 1995; 151: 1666-1673.

76. Alwan WH, Kozlowska WJ, Openshaw PJ. Distinct types of lung disease caused by functional subsets of antiviral T cells. $J$ Exp Med 1994; 179: 81-89.

77. Mosmann TR, Sad S. The expanding universe of T-cell subsets: Th1, Th2 and more. Immunol Today 1996; 17: 138-146.

78. Romagnani S. The Th1/Th2 paradigm. Immunol Today 1997; 18: 263-266.

79. Gern JE, Vrtis R, Grindle KA, Swenson C, Busse WW. Relationship of upper and lower airway cytokines to outcome of experimental rhinovirus infection. $\mathrm{Am}$ J Respir Crit Care Med 2000; 1622: 226-231.

80. Hussell T, Spender LC, Georgiou A, O'Garra A, Openshaw PJ. Th1 and Th2 cytokine induction in 
pulmonary $\mathrm{T}$ cells during infection with respiratory syncytial virus. J Gen Virol 1996; 77: 2447-2455.

81. Coyle AJ, Erard F, Bertrand C, Walti S, Pircher H, Le Gros G. Virus-specific CD8+ cells can switch to interleukin 5 production and induce airway eosinophilia. J Exp Med 1995; 181: 1229-1233.

82. Volovitz B, Faden H, Ogra PL. Release of leukotriene $\mathrm{C}_{4}$ in respiratory tract during acute viral infection. J Pediatr 1988; 112: 218-222.

83. Barnes PJ, Chung KF, Page CP. Inflammatory mediators of asthma: an update. Pharm Rev 1998; 50: 515-596.

84. Gleich GJ. Mechanisms of eosinophil-associated inflammation. J Allergy Clin Immunol 2000; 105: 651-663.

85. Saito T, Deskin RW, Casola A, et al. Respiratory syncytial virus induces selective production of the chemokine RANTES by upper airway epithelial cells. J Infect Dis 1997; 175: 497-504.

86. Noah TL, Henderson FW, Henry MM, Peden DB, Devlin RB. Nasal lavage cytokines in normal, allergic, and asthmatic school-age children. Am J Respir Crit Care Med 1995; 152: 1290-1296.

87. Adamko DJ, Yost BL, Gleich GJ, Fryer AD, Jacoby DB. Ovalbumin sensitization changes the inflammatory response to subsequent parainfluenza infection. Eosinophils mediate airway hyperresponsiveness, m(2) muscarinic receptor dysfunction, and antiviral effects. J Exp Med 1999; 190: 1465-1478.

88. Domachowske JB, Dyer KD, Adams AG, Leto TL, Rosenberg HF. Eosinophil cationic protein/RNase 3 is another RNase A-family ribonuclease with direct antiviral activity. Nucleic Acids Res 1998; 26: 33583363.

89. Pizzichini MM, Pizzichini E, Efthimiadis A, et al. Asthma and natural colds. Inflammatory indices in induced sputum: a feasibility study. Am J Respir Crit Care Med 1998; 158: 1178-1184.

90. Fahy JV, Kim KW, Liu J, Boushey HA. Prominent neutrophilic inflammation in sputum from subjects with asthma exacerbation. J Allergy Clin Immunol 1995; 95: 843-852.

91. Teran LM, Johnston SL, Schroder JM, Church MK, Holgate ST. Role of nasal interleukin-8 in neutrophil recruitment and activation in children with virusinduced asthma. Am J Respir Crit Care Med 1997; 155: 1362-1366.

92. Biron CA, Nguyen KB, Pien GC, Cousens LP, Salazar-Mather TP. Natural killer cells in antiviral defense: function and regulation by innate cytokines. Ann Rev Immunol 1999; 17: 189-220.

93. Moretta L, Biassoni R, Bottino C, Mingari MC, Moretta A. Human NK-cell receptors. Immunol Today 2000; 21: 420-422.

94. Mingari MC, Ponte M, Bertone S, et al. HLA class I-specific inhibitory receptors in human $\mathrm{T}$ lymphocytes: interleukin 15-induced expression of CD94/ NKG2A in superantigen- or alloantigen-activated
CD8+ T cells. Proc Nat Acad Sci USA 1998; 95: 1172-1177.

95. Biron CA. Role of early cytokines, including alpha and beta interferons (IFN-alpha/beta), in innate and adaptive immune responses to viral infections. Sem Immunol 1998; 10: 383-390.

96. Peritt D, Robertson S, Gri G, Showe L, AsteAmezaga M, Trinchieri G. Differentiation of human NK cells into NK1 and NK2 subsets. J Immunol 1998; 161: 5821-5824.

97. Warren HS, Kinnear BF, Phillips JH, Lanier LL. Production of IL- 5 by human NK cells and regulation of IL-5 secretion by IL-4, IL-10, and IL-12. J Immunol 1995; 154: 5144-5152.

98. Walker C, Checkel J, Cammisuli S, Leibson PJ, Gleich GJ. IL-5 production by NK cells contributes to eosinophil infiltration in a mouse model of allergic inflammation. J Immunol 1998; 161: 1962-1969.

99. Humbert M, Menz G, Ying S, et al. The immunopathology of extrinsic (atopic) and intrinsic (nonatopic) asthma: more similarities than differences. Immunol Today 1999; 20: 528-533.

100. Skoner DP, Doyle WJ, Tanner EP, Kiss J, Fireman P. Effect of rhinovirus 39 (RV-39) infection on immune and inflammatory parameters in allergic and nonallergic subjects. Clin Exp Allergy 1995; 25: 561-567.

101. Lin CY, Kuo YC, Liu WT, Lin CC. Immunomodulation of influenza virus infection in the precipitating asthma attack. Chest 1988; 93: 1234-1238.

102. Welliver RC, Wong DT, Sun M, Middleton EJ, Vaughan RS, Ogra PL. The development of respiratory syncytial virus-specific $\operatorname{IgE}$ and the release of histamine in nasopharyngeal secretions after infection. $N$ Engl J Med 1981; 305: 841-846.

103. Alper CM, Doyle WJ, Skoner DP, et al. Prechallenge antibodies: moderators of infection rate, signs, and symptoms in adults experimentally challenged with rhinovirus type 39. Laryngoscope 1996; 106: 12981305.

104. Alper CM, Doyle WJ, Skoner DP, Buchman CA, Cohen S, Gwaltney JM. Prechallenge antibodies moderate disease expression in adults experimentally exposed to rhinovirus strain hanks. Clin Infect Dis 1998; 27: 119-128.

105. Hastings GZ, Francis MJ, Rowlands DJ, Chain BM. Epitope analysis of the $\mathrm{T}$ cell response to a complex antigen: proliferative responses to human rhinovirus capsids. Eur J Immunol 1993; 23: 2300-2305.

106. Gern JE, Dick EC, Kelly EA, Vrtis R, Klein B. Rhinovirus-specific $\mathrm{T}$ cells recognize both shared and serotype-restricted viral epitopes. J Infect Dis 1997; 175: 1108-1114.

107. Parry DE, Busse WW, Sukow KA, Dick CR, Swenson C, Gern JE. Rhinovirus-induced PBMC responses and outcome of experimental infection in allergic subjects. J Allergy Clin Immunol 2000; 105: 692-698. 